\title{
Different Blood Groups Have Different Obesity Levels
}

\author{
Muhammad Imran Qadir and Sana Iqbal* \\ Department of Molecular Biology and Biotechnology, Pakistan
}

*Corresponding author: Sana Iqbal, Department of Molecular Biology and Biotechnology, Pakistan

\begin{abstract}
Objective of this study was to correlate blood grouping with obesity. Total of 178 subjects were participated in this survey. The subjects were the students of Baradin Zakariya University Multan, Pakistan. Presence or absence of antigens on the surface of red blood cells is called blood group system. For checking the obesity level of different blood groups, I performed a survey in different subjects.
\end{abstract}

Keywords: Obesity; Blood grouping

\section{Introduction}

Blood group system is defined based on presence or absence of antigens present on the surface of red blood cells. Two types of blood group system are present ABO and Rh. The ABO blood group system was discovered by Karl Landsteiner. This blood group system is encoded by gene I which is single polymeric gene present on chromosome 9. Blood group A has an antigen on the red blood cells while have B antibody in the plasma. Blood group B has B antigen but with An antibody. Blood group $O$ has no antigens but both antibodies are present in the plasma. A person with blood group $\mathrm{A}$ receives blood from $\mathrm{A}, \mathrm{O}$ and donates to $\mathrm{A}$ and $\mathrm{AB}$. A person with blood group $B$ receives blood from $B, 0$ and donates to $B$ and $\mathrm{AB}$. As the persons with blood group $\mathrm{O}$ are called universal donor so they will donate blood to the all types but receives only from 0 . While $\mathrm{AB}$ persons are called universal acceptor, so they will receive blood from all the types but donate blood only AB persons [1].

Rhesus system is the second type of blood group system which is used in blood transfusion in humans. It has Rd. antigen. The person with $\mathrm{Rh}$ factor is called $\mathrm{Rh}$ positive while person which do not have $\mathrm{Rh}$ factor are called $\mathrm{Rh}$ negative. $\mathrm{Rh}+$ donor is fully incompatible for Rh- recipients [2]. Genetic analysis of blood groups helps to solve the cases of disputed parentage. Obesity is the most worldwide problem. Since 1980 it becomes double throughout the world. A person gets excess fats in body and gains weight greater than normal healthy body weight. This condition is called obesity. Over eating, lack of exercise, diet high in fats, drinks, fast foods etc. all are the causes of obesity. Fat is necessary for our body to get energy but excess fats cause obesity. Obesity increases the risk of cancer, blood pressure, cholesterol levels, respiratory problems, heart diseases etc. Childhood obesity causes the premature death and disability in adulthood. Objective of this study was to correlate blood grouping with obesity.

\section{Materials and Method}

\section{Blood Grouping}

First a needle was used for pricking the finger and extracting blood from it. Then we placed three drops of blood on the slide. Three anti-sera A, B and D were used to check the blood group of the subject. Second, we placed these three anti-sera on the blood slide. Anti-D was used for checking the positivity or negativity of the blood and anti-A and anti-B were used for blood type. Precipitates formation showed the blood type of that subject.

\section{Project Designing}

For checking the obesity level of different blood groups, we performed a survey in different subjects. Each subject told me either he was obese or not. Total of 178 subjects were participated in this survey. The subjects were the students of Baradin Zakariya University Multan, Pakistan.

\section{Statistical Analysis}

Statistical analysis was performed by using MS Excel. 


\section{Results and Discussion}

Different blood groups have different obesity levels are given in the Table 1. Questionnaire based studies in the recent researches have given an important advancement. Similar surveys were also done by Kumar Ganesan, Sharmila Banu Gain, G V Siva Krishnakanth, Dr. Umesh Pralhadrao Lad [3-10].

Table 1.

\begin{tabular}{|c|c|c|c|c|}
\hline Blood groups & \multicolumn{2}{|c|}{ Female } & \multicolumn{2}{c|}{ Male } \\
\hline & Yes & No & Yes & No \\
\hline $\mathrm{A}^{+}$ & $2.24 \%$ & $8.98 \%$ & $0.56 \%$ & $6.17 \%$ \\
\hline $\mathrm{A}^{-}$ & $0 \%$ & $0.56 \%$ & $0 \%$ & $0.56 \%$ \\
\hline $\mathrm{B}^{+}$ & $3.37 \%$ & $24.71 \%$ & $0.56 \%$ & $4.49 \%$ \\
\hline $\mathrm{B}^{-}$ & $1.12 \%$ & $0.56 \%$ & $0 \%$ & $1.12 \%$ \\
\hline $\mathrm{AB}^{+}$ & $1.12 \%$ & $3.37 \%$ & $0 \%$ & $1.68 \%$ \\
\hline $\mathrm{AB}^{-}$ & $0 \%$ & $0.56 \%$ & $0 \%$ & $0 \%$ \\
\hline $\mathrm{O}^{+}$ & $8.98 \%$ & $13.4 \%$ & $1.68 \%$ & $7.8 \%$ \\
\hline $\mathrm{O}^{-}$ & $0 \%$ & $5.61 \%$ & $0 \%$ & $0 \%$ \\
\hline
\end{tabular}

\section{Conclusion}

It was concluded that $\mathrm{O}^{+}$females had highest obesity level and $\mathrm{O}^{-}$and $\mathrm{AB}^{-}$males had lowest obesity level.

\section{References}

1. Qadir MI, Malik SA (2010) Comparison of alterations in red blood cell count and alterations in hemoglobin concentration in patients suffering from rectal carcinoma undergoing 5-fluorouracil and folic acid therapy. Pharmacology online, $\mathrm{Nl}$ 3: 240-243.

2. Qadir MI, Noor A (2018) Anemias. Rare \& Uncommon Diseases. Cambridge Scholars Publishing. Newcastle, England.

3. Qadir MI, Javid A (2018) Awareness about Crohn's Disease in biotechnology students. Global Advanced Research Journal of Medicine and Medical Sciences 7(3): 062-064.

4. Qadir MI, Saleem A (2018) Awareness about ischemic heart disease in university biotechnology students. Global Advanced Research Journal of Medicine and Medical Sciences 7(3): 059-061.

5. Qadir MI, Ishfaq S (2018) Awareness about hypertension in biology students. Int J Mod Pharma Res 7(2): 08-10.

6. Qadir MI, Mehwish (2018) Awareness about psoriasis disease. Int J Mod Pharma Res 7(2): 17-18.

7. Qadir MI, Shahzad R (2018) Awareness about obesity in postgraduate students of biotechnology. Int J Mod Pharma Res 7(2): 14-16.

8. Qadir MI, Rizvi M (2018) Awareness about thalassemia in post graduate students. MOJ Lymphology \& Phlebology 2(1): 14-16.

9. Qadir MI, Ghalia BA (2018) Awareness survey about colorectal cancer in students of M. Phil Biotechnology at Bahauddin Zakariya University, Multan, Pakistan. Nov Appro in Can Study 1(3).

10. Qadir MI, Saba G (2018) Awareness about intestinal cancer in university student. Novel Approaches in Cancer Study 1(3).

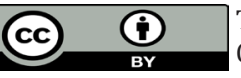

This work is licensed under Creative Commons Attribution 4.0 License

To Submit Your Article Click Here: Submit Article

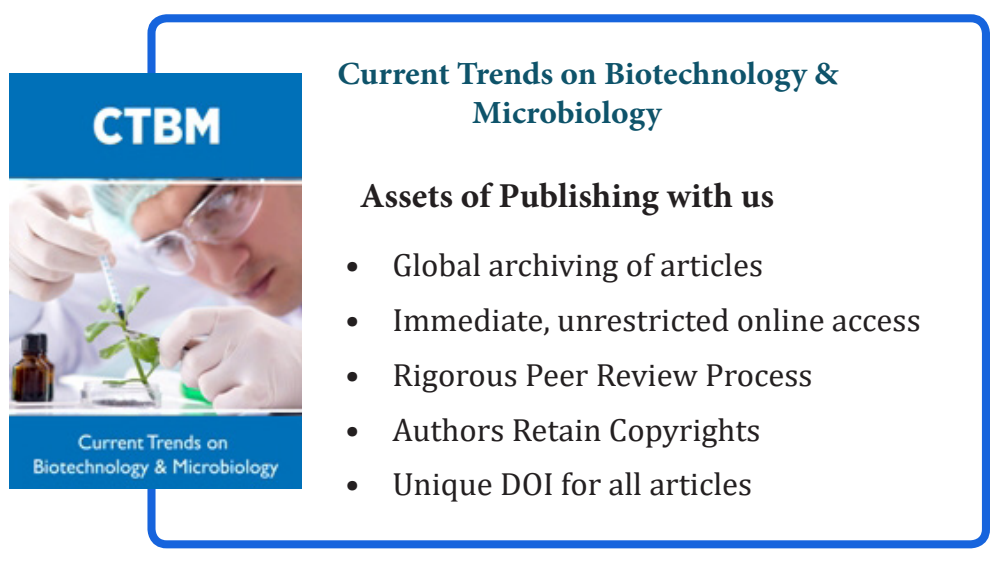

